\title{
Optimization of Process Parameters in MIG Welding of Two Dissimilar Materials
}

\author{
M. S. Amarnath Reddy ${ }^{1}$, Mr. J. Sree Hari ${ }^{2}$, Mr. K. Sai Kiran ${ }^{2}$ \\ ${ }^{1}$ PG. Scholar, ${ }^{2}$ Assistant Professor
}

Sri Venkateswara Institute of Technology, Anantapuram, Andhra Pradesh, India

\begin{abstract}
The joining of dissimilar Aluminum Alloy and Copper aluminum plates of $5 \mathrm{~mm}$ thickness was carried out by technique. Optimum process parameters were obtained for joints using statistical approach. Five different tool designs have been employed to an alyse the influence of rotation speed and traverse speed over the micro structural and tensile properties.
\end{abstract}

In FSW technique, the process of welding of the base material, well below its melting temperature, has opened up new trends in producing efficient dissimilar joints. Effect of welding speed on microstructures, hardness distribution and tensile properties of the welded joints were investigated. By varying the process parameters, defect free and high efficiency welded joints were produced.

The ratio between tool shoulder diameter and pin diameter is the most dominant factor. From micro structural analysis it is evident that the material placed on the advancing side dominates the nugget region. The hardness in the HAZ of 6061 was found to be minimum, where the welded joints failed during the tensile studies.

Keywords: Mig Welding Technique, Haz.

\section{INTRODUCTION}

MIG Welding is a process by which two similar or dissimilar metals may be joined by heating them to suitable temperatures with or without the application of the pressure and without use of filler metal. The filler metal has its melting point either approximately the same as that of the work piece metal or little lower but normally about 430degree centigrade.
During welding the edges of the work piece's to be welded are heated by several ways. Heat may be derived from electric arc, oxy-acetylene or oxyhydrogen flame, black smith fire or chemical reaction as in case of the rm it welding.

\section{AUTOGENEOS WELDING:}

Welding consists of those processes in which similar metals are joined with the help of filler rod of same metal.

EX: mild steel, cast iron.

\section{HETEROGENEOUS WELDING:}

It is a method in which dissimilar metals are joined. The metals being joined are brought up to critical temperature or plastic state and the filler rod is used. The melting point of filler rod less than parent metals for easy melting.

EX: copper<->brass.

\section{CLASSIFICATION OF WELDING:}

Welding is classified into two types. They are

$>$ Fusion (or) non pressure welding

Pressure welding

\section{FUSION (OR) NON PRESSURE WELDING:}

It involves heating of work pieces to be joined to a temperature above the melting point of the metal of the work pieces. This way the fusion of base metal of work pieces takes place and these are joined together without the application of any pressure. Fusion welding involves the use of additional filler metal through an electrode. 


\section{PRESSURE WELDING:}

It involves heating of work pieces to the temperature range in which the base metal of the work pieces becomes plastic and then the work pieces joined together by applying pressure on them. No additional filler metal is used in pressure welding.

\section{SUBMERGED ARC WELDING: Mode of Operation:}

An arc is maintained between the end of a bare wire electrode and the work. As the electrode is melted, it is fed into the arc by a set of rolls driven by a governed motor. Wire feed speed is automatically controlled to equal the rate at which the electrode is melted, thus arc length is constant (similar to MIG/MAG-constant voltage).

\section{Joint Preparation:}

Joint preparation depends on plate thickness, type of joint e.g. circumferential or longitudinal and to some extent on the standards to which the structure is being made. Plates of up to $14 \mathrm{~mm}$ thick can be butt welded without preparation with a gap not exceeding $1 \mathrm{~mm}$ or $10 \%$ of the plate thickness, whichever is the greater. Thicker plates need preparation if full penetration is to be obtained. Variable fit up cannot be tolerated.

\section{Welding Procedure:}

In general the more severe the low temperature notch toughness requirements, the lower the maximum welding current that can be used. This is to minimize heat input and means that a multi pass technique may be required. When welding stainless steels the heat input should be kept low because it has poor thermal conductivity and a high coefficient of expansion compared with mild steel. These two effects lead to overheating and excessive distortion if large diameter wires and high currents are used. Multi-run welds using small diameter wires are therefore recommended for stainless steels and high nickel alloys such as Inconel.

Selection of the correct welding conditions for the plate thickness and joint preparation to be welded is very important if satisfactory joints free from defects such as cracking, porosity and undercut are to be obtained. The process variables which have to be considered are:

1. Electrode polarity

2. Welding Current

3. Electrode Diameter

4. Arc Voltage
5. Welding Speed

6. Electrode Extension

7. Electrode Angle

\section{Principle Of Operation:}

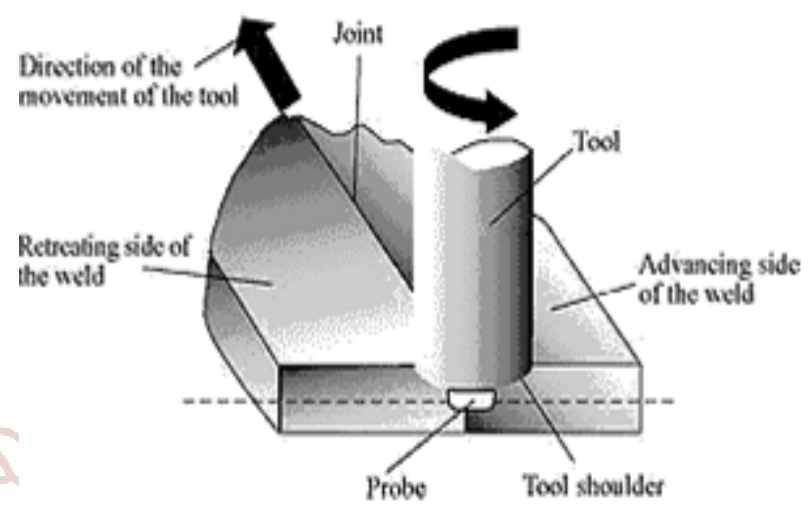

Schematic diagram of the FSW process: Two discrete metal work pieces butted together, along with the tool. The progress of the tool through the joint, also showing the weld zone and the region affected by the tool shoulder, In FSW, a cylindrical-shouldered tool, with a profile of threaded/unthreaded nib is rotated at a constant speed and fed at a constant traverse rate into the joint line between two pieces of sheet or plate material, which are butted together.

Frictional heat is generated between the wear-resistant welding tool shoulder and nib, and the material of the work pieces. This heat, along with the heat generated by the mechanical mixing process and the adiabatic heat within the material, cause the stirred materials to soften without reaching the melting point (hence cited a solid-state process), allowing the traversing of the tool along the weld line in a plasticized tubular shaft of metal.

\section{METHODOLOGY:}

\section{Mig Welding Parameters:}

Tool Rotation and Traverse Speeds

There are two tool speeds to be considered in frictionstir welding; how fast the tool rotates and how quickly it traverses the interface. These two parameters have considerable importance and must be chosen with care to ensure a successful and efficient welding cycle. The relationship between the welding speeds and the heat input during welding is complex but, in general, it can be said that increasing the rotation speed or decreasing the traverse speed will result in a hotter weld. In order to produce a successful weld it is necessary that the material surrounding the tool is hot enough to enable the extensive plastic flow required and mini mise the forces acting on the tool. If the 
material is too cool then voids or other flaws may be present in the stir zone and in extreme cases the tool may break.

\section{Tool Tilt and Plunge Depth:}

A drawing showing the plunge depth and tilt of the tool,

The tool is moving to the left. The plunge depth is defined as the depth of the lowest point of the shoulder below the surface of the welded plate and has been found to be a critical parameter for ensuring weld quality. Plunging the shoulder below the plate surface increases the pressure below the tool and helps ensure adequate forging of the material at the rear of the tool. Tilting the tool by $2-4$ degrees, such that the rear of the tool is lower than the front, has been found to assist this forging process.

\section{Tool Design:}

The design of the tool is a critical factor as a good tool can improve both the quality of the weld and the maximum possible welding speed. It is desirable that the tool material is sufficiently strong, tough and hard wearing, at the welding temperature. Hot-worked tool steel such as AISI $\mathrm{H} 13$ has proven perfectly acceptable for welding aluminum alloys within thickness ranges of $0.5-50 \mathrm{~mm}$ but more advanced tool materials are necessary for more demanding applications such as highly abrasive metal matrix composites or higher melting point materials such as steel or titanium.

\section{WELDING FORCES:}

During welding a number of forces will act on the tool:

$>$ A downwards force is necessary to maintain the position of the tool at or below the material surface.

$>$ The traverse force acts parallel to the tool motion and is positive in the traverse direction.

$>$ The lateral force may act perpendicular to the tool traverse direction and is defined here as positive towards the advancing side of the weld.

$>$ Torque is required to rotate the tool, the amount of which will depend on the down force and friction coefficient (sticking friction).

In order to prevent tool fracture and to minimize excessive wear and tear on the tool and associated machinery, the welding cycle should be modified so that the forces acting on the tool are as low as possible and abrupt changes are avoided.

\section{GENERATION AND FLOW OF HEAT:}

For any welding process it is, in general, desirable to increase the travel speed and mini mise the heat input as this will increase productivity and possibly reduce the impact of welding on the mechanical properties of the weld. At the same time it is necessary to ensure that the temperature around the tool is sufficiently high to permit adequate material flow and prevent flaws or tool fracture.

The welding cycle can be split into several stages during which the heat flow and thermal profile will be different:

Dwell. The material is preheated by a stationary, rotating tool in order to achieve a sufficient temperature ahead of the tool to allow the traverse.

Transient heating. When the tool begins to move there will be a transient period where the heat production and temperature around the tool will alter in a complex manner until an essentially steady-state is reached.

Pseudo steady-state. Although fluctuations in heat generation will occur the thermal field around the tool remains effectively constant, at least on the macroscopic scale.

Post steady-state. Near the end of the weld heat may 'reflect' from the end of the plate leading to additional heating around the tool.

Heat generation during friction-stir welding arises from two main sources: friction at the surface of the tool and the deformation of the material around the tool.

$$
Q_{\text {total }}=\frac{2}{3} \pi \tau \omega\left(R_{\text {shoulder }}^{3}-R_{\text {pin }}^{3}\right)
$$

Where $\omega$ is the angular velocity of the tool, $R$ shoulder is the radius of the tool shoulder and Rpin that of the pin. Several other equations have been proposed to account for factors such as the pin but the general approach remains the same.

\section{MATERIALS AND THICKNESSES:}

Maximum thickness in a single pass is dependent on machine power, but values $\geq 50 \mathrm{~mm}$ are achievable. TWI has welded $75 \mathrm{~mm}$ 6xxx material in a single pass, and larger thicknesses are possible. 
$>2000$ series aluminum $(\mathrm{Al}-\mathrm{Cu})$

$>5000$ series aluminum $(\mathrm{Al}-\mathrm{Mg})$

6000 series aluminum $(\mathrm{Al}-\mathrm{Mg}-\mathrm{Si})$

$>7000$ series aluminum $(\mathrm{Al}-\mathrm{Zn})$

$>8000$ series aluminum $(\mathrm{Al}-\mathrm{Li})$

MMCs based on aluminium (metal matrix
composites):

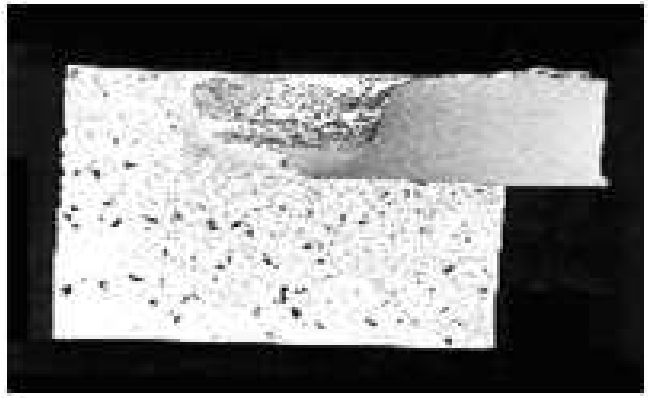

experimental set up of the friction stir welding machine and friction stir welding process are shown in Figures

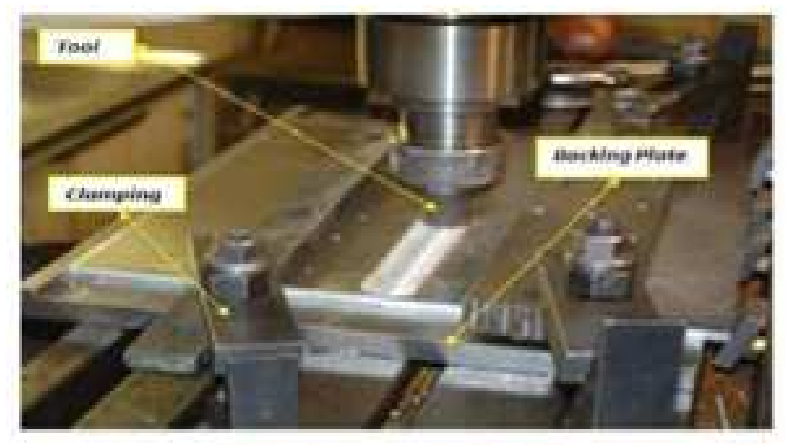

THE TOOL:

An illustration of some types of tools, Each tool has a shoulder whose rotation against the substrate generates most of the heat required for welding. The

Other aluminum alloys of the 1000 (commercially pure), 3000 (Al-Mn) and 4000 (Al-Si) series, aluminum castings,

Other materials successfully welded include:

$>$ Copper and its alloys

$>$ Lead

$>$ Titanium and its alloys

$>$ Magnesium alloys

$>$ Zinc

$>$ Plastics

$>$ Mild and C-Mn steels

$>$ Stainless steel

$>$ Nickel alloys

APPLICATIONS:

Shipbuilding and Marine Industries

\begin{tabular}{|c|c|c|c|}
\hline $\begin{array}{c}\text { Base } \\
\text { metal }\end{array}$ & $\begin{array}{c}\text { Ultimate } \\
\text { tensile } \\
\text { Strength } \\
(\mathrm{MPa})\end{array}$ & $\begin{array}{c}\mathbf{0 . 2 \%} \\
\text { Proof } \\
\text { strength } \\
(\mathrm{MPa})\end{array}$ & $\begin{array}{c}\% \\
\text { Elongation }\end{array}$ \\
\hline $\mathrm{AA6061}$ & 310 & 250 & 12 \\
\hline $\mathrm{Cu}$ & 220 & 125 & 15 \\
\hline
\end{tabular}

$>$ Panels for decks, sides, bulkheads and floors

$>$ Aluminum extrusion

$>$ Offshore accommodation

\section{THE MACHINE:}

The materials, the welding processes and parameters used, and the mechanical properties and chemical compositions of the base materials are described in this chapter. Characterization techniques and the mechanical testing procedures employed to evaluate the welds are also described in detail. The pin on the tool is plunged into the substrate and helps stir the metal in the solid state.

\section{CHEMICAL COMPOSITION OF THE BASE} MATERIALS:

The major part of this study was conducted on aluminum alloys of thickness $6 \mathrm{~mm}$, to make these welds. Initially, to identify the optimal welding parameters, $5 \mathrm{~mm}$ thickness plates were used. The chemical compositions of the base materials used in this study are given in Table 1.

Table 1 Chemical composition of the base materials

\begin{tabular}{|c|c|c|c|c|c|c|}
\hline Material & $\mathrm{Mg}$ & $\mathrm{M}$ n & $\mathrm{Fe}$ & $\mathrm{Si}$ & $\mathrm{Cu}$ & $\mathrm{Al}$ \\
\hline AA6061 & 0.9 & 0.15 & 0.7 & 0.6 & 0.25 & Remaining \\
\hline
\end{tabular}

Mechanical Properties of The Base Materials The mechanical properties of the aluminum alloy 6061 and copper are given in Table 2. The values presented in the table are the average of a minimum of three investigations.

\section{HARDNESS TESTING:}

Hardness testing was conducted using a Vickers hardness testing machine, using a $100 \mathrm{~g}$ load applied for $15 \mathrm{~s}$. Welds were tested for hardness in the as welded condition. The results were averaged over a minimum of 5 tests per sample; more tests were

Transverse tensile specimens with a gauge length of $25 \mathrm{~mm}$ and a width of $6 \mathrm{~mm}$ (overall length: $100 \mathrm{~mm}$ ) were prepared from the weld coupons in an as-welded

\section{TENSILE TESTING:}


International Journal of Trend in Scientific Research and Development (IJTSRD) ISSN: 2456-6470

condition. Room-temperature tensile tests were conducted on three samples as per ASTM E8 (2010) on a universal tensile testing machine dimensions of $\mathrm{t}$

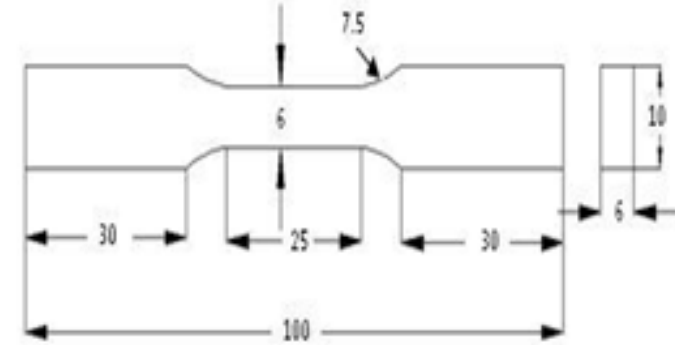

Dimensions of the tensile specimen $(\mathrm{mm})$

\section{RESULTS AND DISCUSSION:}

\subsection{Friction Stir Welding Of Aa6061-Cu:}

Friction stir welding trials were performed using different friction stir welding parameters obtained from literature. The following process parameters (Rotational speed - $800 \mathrm{rpm}$, Welding speed - 40 $\mathrm{mm} /$ minute, Shoulder diameter to pin diameter - 3) were used for friction stir welding to get the defect free good quality welds. Trial and error method were used get these process parameters.

\subsection{Micro Structure:}

The base materials used in the study contained grains elongated in the rolling direction and a large number of eutectic and inter metallic particles. The Thermo Mechanically Affected Zone on either side

Figure Microstructures of base materials AA6061

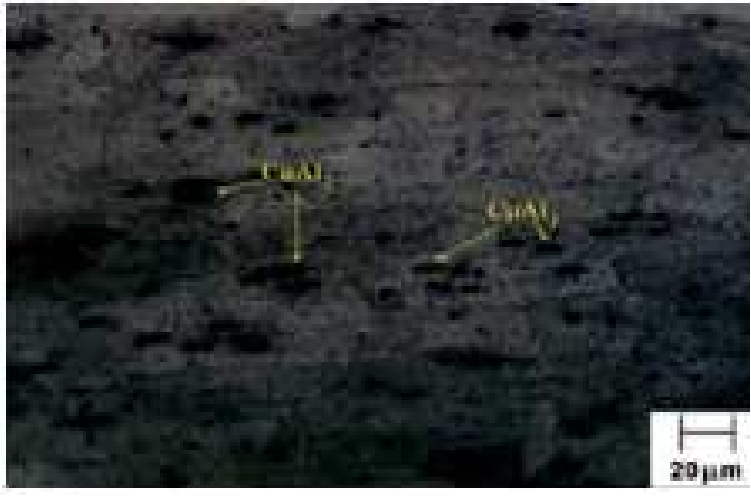

Figure Microstructures of HAZ (AA6061-Cu)

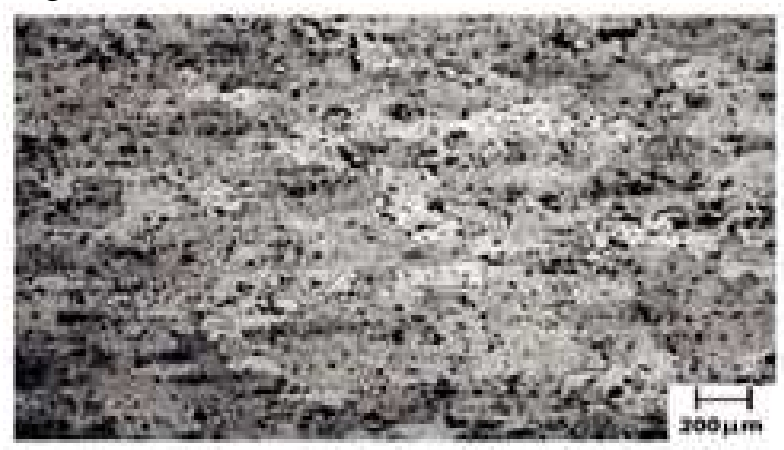

\begin{tabular}{|c|c|c|c|c|c|c|}
\hline \multicolumn{3}{|c|}{$\begin{array}{l}\text { Advancing side } \\
\text { AA6061 }\end{array}$} & \multirow[b]{2}{*}{$\begin{array}{l}\text { NUGG } \\
\text { ET }\end{array}$} & \multicolumn{3}{|c|}{$\begin{array}{l}\text { Retreating side } \\
\text { AA6061 }\end{array}$} \\
\hline $\begin{array}{c}\text { BAS } \\
\text { E }\end{array}$ & HAZ & $\begin{array}{l}\mathrm{TM} \\
\mathrm{AZ}\end{array}$ & & $\begin{array}{l}\mathrm{TM} \\
\mathrm{AZ}\end{array}$ & HAZ & $\begin{array}{c}\text { BAS } \\
\text { E }\end{array}$ \\
\hline $\begin{array}{c}131 . \\
2\end{array}$ & $\begin{array}{c}109 . \\
1\end{array}$ & $\begin{array}{c}113 . \\
3\end{array}$ & 106.7 & $\begin{array}{c}115 . \\
9\end{array}$ & $\begin{array}{c}111 . \\
2\end{array}$ & $\begin{array}{c}130 . \\
1\end{array}$ \\
\hline $\begin{array}{c}129 . \\
8\end{array}$ & $\begin{array}{c}110 . \\
8\end{array}$ & $\begin{array}{c}111 . \\
5\end{array}$ & 108.3 & $\begin{array}{c}112 . \\
9\end{array}$ & $\begin{array}{c}108 . \\
1\end{array}$ & $\begin{array}{c}132 . \\
4\end{array}$ \\
\hline 128 & $\begin{array}{c}117 . \\
8\end{array}$ & $\begin{array}{c}111 . \\
9\end{array}$ & 94.1 & $\begin{array}{c}106 . \\
3\end{array}$ & $\begin{array}{c}104 . \\
4\end{array}$ & $\begin{array}{c}126 . \\
4\end{array}$ \\
\hline $\begin{array}{c}118 . \\
6\end{array}$ & $\begin{array}{c}119 . \\
3\end{array}$ & $\begin{array}{c}113 . \\
2\end{array}$ & 107 & $\begin{array}{c}112 . \\
9\end{array}$ & $\begin{array}{c}117 . \\
8\end{array}$ & $\begin{array}{c}126 . \\
9\end{array}$ \\
\hline $\begin{array}{c}128 . \\
1\end{array}$ & $\begin{array}{c}117 . \\
4\end{array}$ & $\begin{array}{c}105 . \\
8\end{array}$ & 108.7 & $\begin{array}{c}118 . \\
2\end{array}$ & $\begin{array}{c}109 . \\
6\end{array}$ & $\begin{array}{c}127 . \\
8\end{array}$ \\
\hline $\begin{array}{c}122 . \\
8\end{array}$ & $\begin{array}{c}111 . \\
6\end{array}$ & $\begin{array}{c}114 . \\
9\end{array}$ & 107.8 & $\begin{array}{c}117 . \\
2\end{array}$ & $\begin{array}{c}113 . \\
3\end{array}$ & $\begin{array}{c}120 . \\
4\end{array}$ \\
\hline 122. & $\begin{array}{c}108 \\
4\end{array}$ & $\begin{array}{c}107 . \\
8\end{array}$ & 93.8 & $\begin{array}{c}112 . \\
3\end{array}$ & $\begin{array}{c}111 . \\
2\end{array}$ & $\begin{array}{c}121 . \\
2\end{array}$ \\
\hline $\begin{array}{c}119 . \\
9\end{array}$ & $\begin{array}{c}121 . \\
2\end{array}$ & $\begin{array}{c}113 . \\
3\end{array}$ & & $\begin{array}{c}109 . \\
6\end{array}$ & $\begin{array}{c}117 . \\
8\end{array}$ & $\begin{array}{c}126 . \\
4\end{array}$ \\
\hline $\begin{array}{c}124 . \\
4\end{array}$ & $\begin{array}{c}116 . \\
8\end{array}$ & $\begin{array}{c}115 . \\
9\end{array}$ & & $\begin{array}{c}104 . \\
9\end{array}$ & $\begin{array}{c}119 . \\
3\end{array}$ & $\begin{array}{c}121 . \\
9\end{array}$ \\
\hline $\begin{array}{c}122 \\
3\end{array}$ & $\begin{array}{l}120 . \\
2\end{array}$ & $\begin{array}{c}120 . \\
1\end{array}$ & & $\begin{array}{c}112 . \\
3\end{array}$ & $\begin{array}{c}120 . \\
5\end{array}$ & $\begin{array}{c}122 . \\
6\end{array}$ \\
\hline 127. & 115 & $\begin{array}{c}111 . \\
4\end{array}$ & 102.4 & $\begin{array}{c}109 . \\
6\end{array}$ & $\begin{array}{c}108 . \\
3\end{array}$ & $\begin{array}{c}128 . \\
4\end{array}$ \\
\hline $\begin{array}{c}126 . \\
8\end{array}$ & $\begin{array}{c}113 . \\
6\end{array}$ & $\begin{array}{c}109 . \\
2\end{array}$ & 105.2 & $\begin{array}{c}114 . \\
2\end{array}$ & $\begin{array}{c}117 . \\
6\end{array}$ & $\begin{array}{c}127 . \\
6\end{array}$ \\
\hline 91116 & 716 & & $\begin{array}{l}\text { rage Har } \\
\text { Value }\end{array}$ & & & \\
\hline $\begin{array}{c}125 . \\
12\end{array}$ & $\begin{array}{c}113 . \\
13\end{array}$ & $\begin{array}{c}112 . \\
36\end{array}$ & 103.41 & $\begin{array}{c}112 . \\
19\end{array}$ & $\begin{array}{c}113 . \\
26\end{array}$ & $\begin{array}{c}126 . \\
01\end{array}$ \\
\hline
\end{tabular}

\section{CONCLUSION}

From the experiments and the study conducted on the friction stir welding of dissimilar aluminum alloy 6061 to $\mathrm{Cu}$, the following conclusions are drawn.

Friction stir welding can produce defect free butt welds, between AA6061-Cu plates, with a joint efficiency of around 95\% (based on the yield strength of the softer material i.e. AA6061).

$>$ The weld joints were stronger than the softer base material, and the tensile failures occur in the heataffected zone of the alloy 6061.

$>$ The MIG welding process parameters were optimized, with respect to tensile strength of the joint and the optimum level of settings were found. The optimum levels of the rotational speed, transverse speed, and the ratio of shoulder diameter to pin diameter (D/d) are $900 \mathrm{rpm}, 15$ $\mathrm{mm} / \mathrm{min}$ and 2.5 respectively. 


\section{REFERENCES}

1. Amancio-Filho, S.T., Sheikhi, S., Dos Santos, J.F., Bolfarini, C. "Preliminary study on the microstructure and mechanical properties of dissimilar friction stir welds in aircraft aluminium alloys 2024-T351 and 6056-T4", Journal of materials processing technology, Vol. 206, pp. 132-142.

2. ASTM E8/E8M - 09. "Standard test methods for tension testing of metallic materials1", ASTM International.

3. Atallah, M.M. and Hanadi G Salem. "Friction stir welding parameters: a tool for controlling abnormal grain growth during subsequent heat treatment", Materials Science Engineering, Vol. 391, pp.51-59

4. Baeslack III, W.A., Jata, K.V., Lienert, T.J. "Structure, properties and fracture of friction stir welds in a high-temperature $\mathrm{Al}-8.5 \mathrm{Fe}-1.3 \mathrm{~V}-1.7 \mathrm{Si}$ alloy (AA-8009)", J Mater sci., Vol. 41, pp. 29392951.

5. Bala Srinivasan, P., Dietzel, W., Zettler, R., dos Santos, J.F., Sivan, V. "Stress corrosion cracking susceptibility of friction stir welded AA7075AA6056 dissimilar joint", Materials Science and Engineering A, Vol. 392, pp. 292-300.

6. Beathe Heinz., Birgit Skrotzi. "Characterization of a Friction-Stir Welded Aluminum Alloy 6013", Metallurgical and materials transactions B, Vol. 33B, pp. 489-498.

7. Bob Irving. "Scandium Places Aluminum Welding on a New Plateau", Welding Journal, 76, pp. 53-57. 